\title{
Outer space as a global commons and the role of space law
}

\author{
Olavo de O. Bittencourt Neto
}

\section{Charting the legal nature of outer space: Importance and relevance}

Over the past years, the proliferation of space activities and the diversification of space actors have offered plenty of opportunities but also posed challenges to outer space's long-term sustainability. The rapidly transforming space sector and growing global space economy have enabled many satellite applications and services, while outer space and orbital slots have become more congested with an increasing space debris population. The commercialization of space activities has denounced a growing interest in private, non-governmental uses of outer space, including space resources. As such, outer space continues to prove itself as a strategic domain from scientific, economic, and security standpoints.

As far as international law is concerned, novel debates have emerged about the ontological nature of outer space. Incredibly vast, magnificent, and complex by nature, it constitutes a unique domain, unlike anywhere else on Earth. Throughout the years, outer space has been subject to a specific international framework based on legal principles established at the dawn of the Space Age, notably open access to and non-appropriation of outer space.

Space law treaties and international instruments govern space activities and provide relevant input concerning the legal status of outer space. The 1967 Outer Space Treaty (OST), in its first article, solemnly declares that the exploration and use of outer space "shall be the province of mankind". Therefore, a common interest and shared fate await humankind as we advance through 
the cosmos. Collective action, based on international cooperation and mutual assistance, is of the essence. Nevertheless, a universal definition and delimitation of outer space, as a distinct domain on Planet Earth, remains to be multilaterally accorded (Bittencourt, 2015).

Given the evolving nature of space activities and economy, the legal status of outer space has led to intensive debates in various fora. By constituting a resource domain to which all nations have access, but to which none has the right to claim sovereignty, outer space may be understood as an example of global commons - similarly to the high seas, deep seabed, and Antarctica (Buck, 1998, p. 6). Therefore, outer space and its natural resources, including those located at the Moon and other celestial bodies, are not subject to national appropriation by any means.

The legal status of outer space as a global commons is of extraordinary importance and relevance for space law and space policy. Indeed, it influences the application and interpretation of the legal framework developed for the governance of outer space activities, vis-à-vis the domain and its resource units. To accurately assess this scenario, a comparative approach is followed. The specific features of global commons and legal ramifications justify further appraisal to comprehend definitions and correlated concepts well.

\section{Key problems and conflicts}

In space law as in space policy, words matter. By legally classifying outer space as a global commons, relevant political consequences, both national and international, naturally ensue. In order to properly understand the nuances and avoid misconceptions, one should revisit principles of international law. Centuries of customs, often based on Roman law concepts, have led to important regulations and definitions. The proper evaluation of those concepts may illuminate the path forwards.

\section{Global Commons Concept}

Legally defining "global commons" has proved to be a challenge, leading to incompatible views. Global commons are socially constructed, as explained by John Vogler, being determined by "shifts in human knowledge, capability and perceptions of scarcity" (Vogler, 2012, p. 61). As a legal concept, its roots may 
be traced back to Roman law. More specifically, reference should be made to the notions of res nullius and res communis, applicable to domains not subjected to rights of a specific subject. Res nullius is understood as encompassing things belonging to no one or areas free to be acquired by occupatio. ${ }^{1}$ Terrae nullius, a derivative international law concept, is applicable to unclaimed areas that may be occupied by states (Rose, 2003; Shaw, 2017, p. 372).

Not subjected to exclusive sovereignty, global commons may either be unowned resource domains, or deemed as belonging to the international community in totum. Soroos explains that unowned domains can be regarded as commons if generally understood that they cannot be claimed by any individual actor, neither partially nor as a whole. A regulatory scheme may eventually be accorded by users, to reflect shared interests. On the other hand, domains considered as belonging to the international community presume that all states are their partial owners, therefore legitimized to take part in the decision-making processes related to its uses (Soroos, 2001, p. 45).

Managing natural resources located in global commons is of fundamental relevance to the international community in general, due to their overall significance. Although commons are not subject to appropriation, users may have access to its resource units, either in accordance with a system of "common pool resources", which guarantees open access to all parties without restrictions, or through a limited access mechanism, based on international regimes governing restrictions and controls, reflecting the specificities of each area of concern (Soroos, 2001, p. 42). Traditionally, non-appropriation of commons combined with free transit and orderly access to strategic assets are deemed as key provisions for sustaining peace and development (Vogler, 2012).

Besides the collective interest and availability to the world community, another relevant feature of a global commons is that its resource units, whether renewable or non-renewable, are often finite and subtractive (Dolšak \& Ostrom, 2003, p. 7). Accordingly, natural resources found therein are limited, and exploitation by one actor makes them unavailable to others (Soroos, 2001, p. 43). ${ }^{2}$ Due to the inherent finitude of the resource units therein, Garret Hardin famously identified a potential for "tragedy", i.e., the "the solemnity of the remorseless working of things" (1968, p. 1244). Therefore, social arrangements are required to preserve those domains from misuse and overuse, for the benefit of all.

In accordance with Elinor Ostroom, sustainable management of common pool resources may be achieved based on eight core principles: clearly defined boundaries; congruence between appropriation and provision rules and local 
conditions; collective-choice arrangements; monitoring; graduated sanctions; conflict-resolution mechanisms; minimal recognition of rights to organize; and finally, in the case of larger common-pool resources, organization in multiple layers of nested enterprises (2015, p. 90).

During the last decades, international regimes have been developed to deal with the vast array of issues and potential conflicts involving areas not subjected to exclusive national authority. Global commons' regimes provide mechanisms to internationally regulate exploration and use of those domains and their resource units, towards accommodation of diverging interests, coordination of actions and promotion of collective choices processes, thus contributing to overall sustainability (Sutch \& Roberts, 2019).

Yet, experience reveals that governing global commons in a coordinated, peaceful, and prosperous manner is, as observed by Carla P. Freeman, a very challenging task, due to their interconnectivity and complexity, "not only in terms of the resources they contain and the functions they perform, but also in the diversity of actors who use them and interact with each other" (2016, p. 18). Nives Dolšak and Elinor Ostrom concluded that, the more complex the system, the more difficult it becomes for users to agree on common rules addressing negative externalities derived from exploitation (2003, p. 14).

\section{Outer Space as a Global Commons}

Through a careful study of space law treaties and instruments, fundamental territorial attributes of outer space may be identified. Equal access to outer space, as a domain, is secured to all nations, which are encouraged to cooperate in view of shared interests. Additionally, outer space cannot be nationally appropriated, including by means of use and occupation.

The OST stipulates that outer space is to be explored and used for peaceful purposes only, and constitutes a domain to which no nation can assert sovereignty. Considered as the "province of (hu)mankind", outer space is an international territory, where activities should be conducted for the benefit and in the interest of all nations, irrespective of their degree of economic and scientific development.

Article II OST codified the principle of non-appropriation of outer space, a basic tenet of space law. Accordingly, no state has the right to claim Earth orbits or celestial bodies under its sovereignty, as if they were "res nullius" and thus open to traditional methods of occupation. The principle emerged during 
the early days of the Space Age and has been contemplated by different UN General Assembly Resolutions. ${ }^{3}$

As a rule, the principle of non-appropriation was consolidated after the first manmade satellite reached orbit: the soviet Sputnik 1, on 4 October 1957. Although passing over the territories of the many different states associated with its flightpath, no formal protest for violation of national air space was presented before the USSR (Reynolds \& Merges, 1998, p. 70). The "Sputnik precedent" served as basis for consolidating an international customary norm, according to which outer space constitutes a different realm in relation to territorial airspace - one where national sovereignty does not apply (Soares, 2002, p. 82).

Another equally important Space Law principle is the one that regards the Moon and other celestial bodies of the solar system as common heritage of mankind, as enshrined in Article 11 of the 1979 Moon Agreement (MAG). It originated from the need of the international community to ensure the availability of resources and counter the first-come-first-served rule, which would in principle be disadvantageous to developing nations (Buck, 1998, p. 29). However, questions involving possible conflicts with OST and commercial exploitation of space resources explain the reluctance of spacefaring nations to subscribe to the MAG. Diverging views in relation to the principle of common heritage of humankind have often led to failure in regulating the exploitation of natural resources through comprehensive and widely accepted legal frameworks (Lee, 2012, p. 16).

The OST, despite many indications, does not categorically state the legal status of outer space. According to Marvin Soroos, the legal status of outer space remains ambiguous; while some OST provisions could possibly remit to the common heritage doctrine - for instance, the principle of non-appropriation - there is no explicit reference in the treaty, which does not specifically address the issue of ownership of space resources (Soroos, 2001, p. 47). Therefore, the review of international practices and positions is relevant for identifying the cornerstones of this study.

\section{Actors and institutions}

Nowadays, space activities are regarded as strategic assets for the development of each and every nation. The evolution of space technology combined 
with growing economic interest on space capabilities have introduced to the equation new space actors, including emerging nations, industry, and intergovernmental and non-governmental international organizations. Institutions play a relevant part in shaping and implementing policies, as well as providing a forum for concerted action. By evaluating the behavior of space actors and institutions in relation to current demands, the contours of the legal nature of outer space become more distinguishable.

\section{Space Resources}

Growing interest on space resource activities have led, in recent times, to revaluation of the legal status of outer space. The exploration, exploitation, recovery, and use of space resources, understood as extractable and/or recoverable resources found in situ in outer space, have enjoyed increasing relevance in the global agenda. This results among others from technological advancements and the elaboration of viable business models, related to space resource activities. Geopolitical as well as economic interests have driven states towards efforts to clarify the applicable legal framework, both in the domestic and in the international levels.

On this regard, the US Commercial Space Launch Competitiveness Act, of 2015 (H.R. 2262) states that American citizens, engaged in commercial recovery of an asteroid resource or a space resource, "shall be entitled to any asteroid resource or space resource obtained, including to possess, own, transport, use and sell the asteroid resource or space resource obtained in accordance with applicable law, including the international obligations of the United States" ( $\$$ 51303). To avoid any infringement of the OST non-appropriation principle, Section 403 of said Act clarified that the USA does not assert sovereignty or sovereign or exclusive rights or jurisdiction over, or the ownership of, any celestial body.

In 2016, the International Institute of Space Law (IISL) approved a position paper on space resource activities. The document recognized the US Commercial Space Launch Competitiveness Act as a valid OST interpretation, but called attention to possible future outcomes. ${ }^{4}$ Just one year later, Luxembourg became the first European country, and the second worldwide, to approve a national legal framework on the exploration and use of space resources. As far as the Middle East is concerned, the United Arab Emirates considered a similar path in its Federal Law of 2019. Other States are considering national legislations in the same direction, thus domestically regulating space resource rights and activities. 
Recently, through an Executive Order on encouraging international support for the recovery and use of space resources, issued on April 6, 2020, the American government offered an additional relevant assessment, according to which "outer space is a legally and physically unique domain of human activity, and the United States does not view it as a global commons." The main concern of the executive order appears to be the legality of space resource activities, in consistency with applicable law. Neither the legal nature of outer space nor its definition was specifically addressed. Such document must be appraised vis-à-vis the NASA Artemis Lunar Exploration Program, which envisions sustainable lunar exploration by the end of the decade.

In view of growing interest in space resource activities, the Hague International Space Resources Governance Working Group was constituted, with the mission of promoting international cooperation and multi-stakeholder dialogue towards consideration of an international framework. During the Hague Working Group's final session, held at Luxembourg University in 2019, a total of 20 building blocks were approved, designed to provide the foundations for international discussions on a potential international framework. Additionally, a Commentary was prepared by a Drafting Committee and approved by the Working Group Secretariat, clarifying the content of each building block while providing addition observations (Bittencourt et al., 2020).

\section{Space Security}

The legal notion of outer space as global commons has also been questioned in view of space security concerns, aimed at projecting power in outer space and responding to envisaged threats to satellite systems. Under the growing risk of an arms race in outer space, which could spark an actual conflict of dramatic proportions, diplomacy has been put under stress. Confidence building initiatives, as well as further regulation of military uses of outer space, are to be pursued in order to acknowledge common interests.

Among the most important focus areas involving international space security, reference should be made to dual-use technology, export control regulations, cybersecurity, space-based defence systems, space traffic management, and military uses of outer space (Schrogl et al., 2020, pp. 5-7). Fabio Tronchetti properly points out that a coherent and unitary legal framework regulating military activities in outer space still awaits enactment (2013, p. 71). Recent national defence initiatives, including the constitution of the US Space Force in 2019 , testify that the issue has entered the order of the day. 
Important studies are being developed worldwide in relation to space security, including by international organizations. The prevention of an arms race in outer space has been considered by the United Nations Conference on Disarmament for a long time, with a working group being constituted in 1985. A Draft Treaty on Prevention of the Placement of Weapons in Outer Space and of the Threat or Use of Force Against Outer Space Objects (PPWT) was submitted therein by Russia and China, in 2008. Debates continue at the Conference on Disarmament (CD), reflecting the complications of such a politically charged issue (Schrogl et al., 2020, p. 100-106).

Reference should also be made to the multi-stakeholder collaborative project to develop the Manual on International Law Applicable to Military Uses of Outer Space (MILAMOS). By bringing together international experts of diverse fields, relevant perspectives have been acknowledged towards the development of a neutral framework. Those results may affect the decision making in relation to military activities in outer space, avoiding dangerous misconceptions and thus favoring the peaceful resolution of disputes.

\section{Long-term Sustainability}

The long-term sustainability of outer space is also conclusively linked with the international protection of global commons, safeguarding this domain from relevant threats. As such, the UNCOPUOS Scientific and Technical Subcommittee established a Working Group on the topic in 2010, which led to the approval of international guidelines nine years later. Members accepted to take voluntary measures to address policy and regulatory framework for space activities, safety of space operations, international cooperation, capacity-building and awareness, and scientific and technical research and development.

The guidelines advocate that outer space should remain an operationally stable and safe environment, sustained for peaceful purposes, as the province of humankind. Therefore, risks need to be mitigated, through concerted measures.

Threats to the long-term sustainability of outer space were identified, namely proliferation of space debris, the increasing complexity of space operations, the emergence of large constellations, and the increased risks of collision and interference with the operation of space objects. To avoid harm to outer space as an environment as well as the safety of space operations, international coop- 
eration by States and international intergovernmental organizations is advised by the UN Guidelines.

\section{Comparative assessment of regulatory approaches and solutions}

As societal needs naturally evolved, legal regimes were accorded regarding international territories such as Antarctica, the high seas and outer space. Each one contemplates specific rules, designed to address areas environmentally very distinctive from each other. Based on a comparative assessment, one may identify international legal patterns related to global commons in International Law, making it possible to produce observations and to develop advanced insights on the legal status of outer space. Consequently, solutions may be envisaged, considering the diplomatic debates in various international fora.

\section{Antarctica}

Much like the OST, the Antarctic Treaty is the cornerstone of an entire international legal system, which has proved its value, withstanding the test of time as well as political, technological, and economic change. ${ }^{5}$ It contemplates rules applicable to Antarctica, a large ice-covered landmass in the form of an island, located south of $60^{\circ}$ south latitude (Shaw, 2017, p. 399).

Signed in 1959, the Antarctic Treaty established the basis for international peaceful cooperation in a vast, pristine, and strategic continent, in accordance with shared values. An elegant instrument, quite concise despite arduous negotiations, the Antarctic Treaty has succeeded in keeping the most inhospitable continent on Earth devoted to peaceful purposes and as a nonnuclear realm. The Antarctic Treaty has been concluded for an indefinite period of time, without an expiration date, and up to this moment has never itself been modified. $^{6}$

In view of competing claims to territorial sovereignty over sectors in Antarctica, some of them overlapping each other, the possibility of international disputes seemed quite real at the time the document was negotiated. Addressing those concerns, the Antarctic Treaty recognized that "it is in the interest of all mankind that Antarctica shall continue forever to be used exclusively for 
peaceful purposes and shall not become the scene of international discord" (Preamble).

Arguably, the key provision of the Antarctic Treaty is its Article 4, which has acknowledged but, at the same time, "frozen" claims to territorial sovereignty while the agreement is in force. The idea of sovereign neutrality was adopted therein, arguably the vital building block for the development of the whole Antarctic Treaty System (ATS). As explained by Karen N. Scott, Article 4 did not resolve the sovereign disputes but has enabled the parties to manage them, not impeding international cooperation (Scott et al., 2020, p. 42).

Despite the geopolitical scope originally considered during the preparation of the Antarctic Treaty, soon the Consultative Parties leaned towards an environmental approach, as far as the global governance of the region is concerned, to preserve and conserve such a fragile biome. First, the Consultative Parties negotiated Agreed Measures, then voluntary standards and, finally, specific treaties, including on Antarctic seals, in 1972, and marine leaving resources, in 1980. Mineral exploration and exploitation of Antarctica has proven to be a much more complicated issue, due to the clear potential of environmental harm.

In 1988, after a period of intense debates, the "Convention on the Regulation of Antarctic Mineral Resource Activities" was concluded. Nevertheless, it never came into force, much due to the negative reaction that followed its conclusion, based on relevant environmental concerns. The 1991 Protocol on the Environmental Protection created an integrated environmental regime in Antarctica, enacted to protect dependent and associated ecosystems, and has proven its significant value to the furtherance of International Environmental Law.

One of its core provisions is Article 2, which designated Antarctica as a "natural reserve, devoted to peace and science." Additionally, Article 3 introduced environmental principles and, in its letter (c), required "prior assessment of, and informed judgement about, impacts on the Antarctic Environment" of activities undertaken in the region. The environmental impact assessment was further considered by Article 8 .

As far as activities related to Antarctic mineral resources are concerned, other than scientific research, they have been prohibited by the 1991 Protocol, in accordance with Article 7. Such a definitive statement, as other provisions, may be reconsidered after the expiration of fifty years from the date of the protocol's entry into force, that is, 2048, at an international conference, if 
so requested by any of the Antarctic Treaty Consultative Parties (Article 25, paragraph 2).

\section{High Seas and Deep Seabed}

Similarly, the high seas have been recognized by the United Nations Convention on the Law of the Seas (UNCLOS), of 1982, as a domain not subjected to national appropriation. Composed of maritime areas not included as part of territorial seas, economic exclusive zones, or internal waters, the high seas have justified intense international debates for centuries, in order to avoid conflict and support communication.

As explained by Malcolm N. Shaw, "the seas were at one time thought capable of subjection to national sovereignties. The Portuguese in particular in the seventeenth century proclaimed huge tracts of the high seas as part of their territorial domain, but these claims stimulated a response by Grotius who elaborated the doctrine of the open seas, whereby the oceans as res communis international law were to be accessible to all nations but incapable of appropriation. This view prevailed, partly because it accorded with the interests of the North European states, which demanded freedom of the seas for the purposes of exploration and expanding commercial intercourse with the East" (2017, p. 410).

UNCLOS, in Article 87, expanded the provision of the Geneva Convention on the High Seas, of 1958 by recognizing six freedoms of the high seas: the freedom to navigate, freedom of overflight, freedom to lay submarine pipelines and cables, freedom of fisheries, freedom to construct artificial islands and other installations, and freedom of scientific research. Accordingly, as explained by Jan Klabbers, "these freedoms, while extensive, are not unlimited; their exercise must take place with 'due regard' for the interest of other states, and the high seas must be used for peaceful purposes” (2013, p. 241).

In essence, the freedoms of the high seas characterize a major feature: no State may acquire sovereignty over said domain. Notwithstanding, the flag State shall enjoy jurisdiction over its vessels in the high seas, thus being authorized to enforce its national rules and national regulations. The nationality of the ship is dependent upon the flag it flies, but UNCLOS, in Article 91, stipulates that there must be a genuine link between the State and the ship.

The deep seabed and ocean floor and the subsoil thereof, related to maritime areas beyond national jurisdiction, were recognized by UNCLOS as "common 
heritage of mankind", following the footsteps of UNGA Resolution 2749 (XXV), of 17 December 1970. Part IX of UNCLOS introduced an intricate and complex legal system in that regard, to be managed by the International Seabed Authority, an international association to which all state Parties are members.

In accordance with Antonio Cassese, "as early as 1967, the Maltese ambassador Arvid Pardo launched the notion of the common heritage of mankind in the UNGA. He noted that new technology as well as fresh developments in oceanography were making it possible for mankind to benefit from the 'immense wealth' existing on the seabed and the ocean floor beyond national jurisdiction” (2005, p. 92).

The initial seabed mining regime proved to be problematic, facing resistance specially from Western nations. Ultimately, Part IX of UNCLOS would be later modified by an implementation agreement of 1994, composed by nine, quite detailed, annexes. In accordance with the system developed therein, deep seabed mining was envisioned as being conducted by a private consortium, with the possibility of creating an Enterprise, under the authority. Compulsory transfer of technology mechanisms was also envisaged. Throughout the following years, several contracts have been accorded between the authority and the consortia and governments (Klabbers, 2013, p. 243).

\section{Geostationary Orbits and the Radio Spectrum}

The geostationary orbit (GEO) is also of relevance, although it constitutes a specific segment of outer space. International law currently regards GEO as a limited natural resource that shall be used to benefit all humankind, following the principle of equitable access to states (Bittencourt, 2015, p. 30).

Located at $36,000 \mathrm{~km}$ of altitude from sea level, GEO is important for strategic uses since space objects found therein move approximately at the same speed as the Earth's rotation. In the words of Susan Buck, GEOs are spatial-extension resources that lack corporeal existence. Limited in number but of major relevance to several strategic space activities, including telecommunications, GEOs "may be occupied by only one user at a time, but they are not consumed or extracted” (1998, p. 137).

For a long time, access to GEO was restricted to major space-faring nations, and a rudimentary access system of "first come, first serve" was experienced. As telecommunication satellites' political and economic value have become worldly recognized, including by developing nations, the regulated access to 
GEOs and radio spectrum justified multilateral action towards effective international regulation.

The radio spectrum may be qualified as a limited natural resource, as has been acknowledged by the International Telecommunication Union (ITU). One of the earliest international intergovernmental organizations, the ITU, was constituted in 1865 as the International Telegraph Union. Its fundamental documents are the ITU Convention, including the basic legal text, as developed and amended by successive Plenipotentiary Conferences, and the ITU Convention, which complements the former.

Sustainability in GEO, especially in relation to frequency band allocation, depends upon specific practices and organized procedures to avoid overcrowding and harmful interferences. ${ }^{7}$ The International Frequency Registration Board (IFRB), described by the ITU Convention, is responsible for registering frequency assignments. Following the ITU terminology, allocation is the decision of the ITU Member States to connect a specific radiocommunication service with a certain frequency band and the entry of this decision into a binding international table of frequency allocations (Masson-Zwaan \& Hofmann, 2019, p. 141).

The international regulation of GEOs would be challenged by equatorial States in 1976, through the Bogotá Declaration, which claimed sovereign rights over the area, reflecting preoccupation of developing nations in relation to access and utilization of said orbits. The instrument failed to obtain international recognition due to apparent conflict with the OST, but its claims have survived in the national legislation of some states.

\section{Managing diplomatic processes towards effective solutions}

Since outer space constitutes an example of global commons, free from any form of national appropriation and harboring valuable natural reserves, space activities shall acknowledge shared and correlated interests. International cooperation is of the essence, to assure due regard for the corresponding concerns of all nations. International policy initiatives are to be accorded and conjugated to secure the long-term sustainability of space activities. If successful, these initiatives will contribute to a consensus on the fair and responsible use of outer space and support sustainable space activities. 
Conflicting political perspectives may hamper legal classifications to be multilaterally accorded. Since 1966, the topic of the definition of outer space has been under discussion at the UNCOPUOS Legal Subcommittee, together with the delimitation of the frontier between outer space and national air space. Due to the members' different views, no accord has yet been accomplished (Benkö \& Plescher, 2013, p. 31-40).

Internationally, certain strategic domains have been regarded as the common heritage of humankind, justifying the establishment of institutions and mechanisms to manage those areas. The general purpose has been to ensure that resource exploitation is conducted in a manner that benefits all while considering the interests of under-developed nations and States not engaged in such activities (Gorove, 1972, p. 395; Vogler, 2012, p. 66; Mickelson, 2019, p. 640). Legal regimes have been constituted with specific obligations, such as the restriction to peaceful purposes, the use of resources in the common good, environmental protection, as well as benefit-sharing mechanisms (Soroos, 2001, p. 45; Vogler, 2012; Sutch \& Roberts, 2019, p. 1294).

The commercial exploitation of natural resources, located in common heritage areas, is indeed of great significance. According to Karin Mickelson, even though the convenience of exploiting those resources may in due course be questioned, especially in view of potential environmental impacts, the UNCLOS deep seabed regime, for instance, accepts that the common heritage of humankind represents limitations rather than a prohibition to those activities (Mickelson, 2019, p. 659-663).

The legal concept of the common heritage of humankind still awaits to be universally accepted by the international community (Lee, 2012; Mirzaee, 2017; Mickelson, 2019). Indeed, it has been subject to different interpretations, occasionally reflecting regional perspectives and demands. On the one hand, many developed nations have favored a more restrictive approach, granting states access to the benefits derived from the resources. On the other hand, many developing countries have supported benefit-sharing mechanisms to exploit resource items located at common heritage sites. To be developed on an equitable basis, those mechanisms would be applicable as compensation for depriving other parties of access to extracted resources (Lee, 2012, p. 14).

As envisioned by the common heritage of humankind frameworks, benefit-sharing should be understood as a distributive justice concept, equalizing disparities between nations. As such, it may encompass a wide range of initiatives beyond mere financial contributions. Possible cooperative alternatives include the development and exchange of technologies on a fair and 
reasonable basis, joint ventures, educational and capacity-building programs, as well as shared management of resources and related information. In this context, Siavash Mirzaee affirms that the concept of common heritage has become "a protecting instrument for vital resources belonging to all human beings" (Mirzaee, 2017, p. 103).

\section{Contribution to space policy research}

The present study intends to contribute with debates and studies on the legal nature of outer space, considering the applicable legal framework. By revisiting international law and, more specifically, space law, conclusions may be advanced, including that outer space constitutes a global commons as a matter of fact and law. To begin with, outer space, as the province of humankind, is open for exploration and use by all nations. No discrimination is allowed, and freedom of access to all areas of celestial bodies is assured. International cooperation shall be facilitated and encouraged because of shared and common interests.

Furthermore, outer space constitutes an international territory, not subject to national appropriation. Those rules are also applicable to celestial bodies in the solar system, including the Moon, planets, and asteroids. A legal frontier, still undelimited, exists between territorial air space, under national control and jurisdiction, and outer space, where no claim of sovereignty is authorized.

Last but not least, outer space as a domain should not be confused with the natural resources located therein. Managing global commons' resource units is of fundamental relevance to the international community due to their overall significance. Due regard to the corresponding interests of all nations and humankind is of high priority. Orderly access to strategic assets, such as space resources and orbital positions, is critical for peaceful and sustainable space activities.

Based on a detailed review of international principles and instruments, proper interpretation of applicable rules naturally ensues. Outer space should be regarded as an example of global commons since constituting a resource domain to which all nations have legal access but to which none has the right to claim sovereignty. Through a comparative study on other global commons instances, related definitions and assumptions have been properly underlined 
and identified. Political and economic considerations were nevertheless taken into account, as well as current developments and demands.

The ontological nature of outer space has been herein identified as global commons, and the international community should consider it. Although this categorization results from a legal study, its relevance to space policy is undeniable. Since the use and exploration of outer space shall be the province of humankind, international cooperation is of the essence to secure the long-term sustainability of outer space and assure an enabling environment for space activities. Due regard for the corresponding interests of all space actors is critical for the sustainable exploration and use of the outer space domain. The balancing act between needs and wants $v i s$ - $\grave{a}$-vis outer space requires proper identification of its legal nature, thus appropriately realizing the applicable rules of behavior.

\section{Endnotes}

1. 'In law, 'occupation' was a means of peaceably acquiring sovereignty over territory otherwise than by cession or succession": Western Sahara Advisory Opinion, International Court of Justice, 1975, p. 101.

2. "Finite resources are subject to being depleted, either permanently or temporarily, depending upon whether they are renewable": Soroos, 2001, p. 43.

3. UNGA Resolutions 1721 (XVI), of 1961, and 1962 (XVIII), of 1963, contemplated the same rule, i.e., that outer space, including celestial bodies, could not be subjected to national appropriation of any kind.

4. Available at: http://www.iislweb.org/docs/SpaceResourceMining.pdf, accessed on 17 December 2020.

5. The Antarctic Treaty System is composed of the Antarctic Treaty (1959), Agreed Measures for the Conservation of Antarctic Fauna and Flora (1964), Convention for the Preservation of Antarctic Seals (1972), Convention on the Conservation of Antarctic Marine Living Resources (1980). The Protocol on Environmental Protection (1991) is not yet in force.

6. Article XII.

7. "To work effectively, satellites must be at least 18 kilometres (11.2 miles) apart and operate on different radio frequencies, although to some extent this depends on the technology used for intersatellite communication. In theory, 2,000 satellites could operate in geostationary orbit, but this is more than necessary: as few as three satellites placed in orbit could serve the entire globe" (Buck, 1998, p. 158). 


\section{Bibliography}

Benkö, M. \& Plescher, E. (2013). Reconsidering the Definition/Delimitation Question and the Passage of Spacecraft through Foreign Airspace. The Hague: Eleven.

Bittencourt Neto, O. de O. (2015). Defining the Limits of Outer Space for Regulatory Purposes. Cham, Switzerland: Springer.

Bittencourt Neto, O. de O., Hofmann, M., Masson-Zwaan, T. \& Stefoudi, D. (2020). Building Blocks for the Development of an International Framework for the Governance of Space Resource Activities: A Commentary. The Hague: Eleven.

Buck, S. (1998). The Global Commons: An Introduction. Washington, D.C.: Island Press.

Cameron, L. \& Everly, R. (2010). Conceptualizing the Administration of Territory by International Actors, The European Journal of International Law, 21(1), 221-244. DOI:10.1093/ejil/chq014.

Casella, P. B. (2009). Direito Internacional dos Espaços. Leiden, The Netherlands: Atlas.

Cassese, A. (2005). International Law, 2nd edn. Oxford: Oxford University Press.

Dolsak, N. \& Ostrom, E. (eds) (2003). The Commons in the New Millennium: Challenges and Adaptations. Cambridge, MA: MIT Press.

Freeman, C. P. (2016). The Fragile Global Commons in a World in Transition, SAIS Review of International Affairs, 36(1), Winter-Spring, 17-28. DOI: https://doi.org/ 10.1353/sais.2016.0005.

Gál, G. (1969). Space Law. Leiden, The Netherlands: A. W. Stijhoff.

Gorove, S. (1972). The Concept of "Common Heritage of Mankind": A Political Moral or Legal Innovation, San Diego Law Review, 9(3), 390-403.

Hardin, G. (1968). The Tragedy of the Commons, Science, 162(3859), 1243-1248. DOI: $10.1126 /$ science.162.3859.1243.

Hobe, S. (2007). Outer Space as the Province of Mankind: An Assessment of 40 Years of Development. In Proceedings of the Fiftieth Colloquium on the Law of Outer Space. The Hague: Eleven.

Jasentuliyana, N. (coord.) (1992). Space Law: Development and Scope. Westport, CT: Praeger Publishers.

Jasentuliyana, N. \& Lee, R. S. K. (eds) (1979). Manual on Space Law. New York, NY: Oceana.

Kayser, V. (2001). Launching Space Objects: Issues of Liability and Future Prospects. Boston, MA: Kluwer Academic Publishers.

Klabbers, J. (2013). International Law. Cambridge: Cambridge University Press.

Lachs, M. (2010). The Law of Outer Space. Leiden: Martinus Nijhoff.

Lee, R. J. (2012). Law and Regulation of Commercial Mining of Minerals in Outer Space. Cham, Switzerland: Springer.

Masson-Zwaan, T. \& Hofmann, M. (2019). Introduction to Space Law, 4th edn. Alphen aan den Rijn: Wolters Kluwer.

Mickelson, K. (2019). Common Heritage of Mankind as a Limit to Exploitation of the Global Commons, The European Journal of International Law, 30(2), 635-663. DOI: $10.1093 /$ ejil/chz023.

Mirzaee, S. (2017). Outer Space and Common Heritage of Mankind: Challenges and Solutions, RUDN Journal of Law, 21(1), 102-114. DOI: 10.22363/2313-2337-2017-21-1-102-114.

Ostrom, E. (2015). Governing the Commons: The Evolution of Institutions for Collective Action. Cambridge: Cambridge University Press. 
Reynolds, G. H. \& Merges, R. P. (1998). Outer Space: Problems of Law and Policy, 2nd edn. Colorado: Western Press.

Rose, C. M. (2003). Romans, Roads, and Romantic Creators: Traditions of Public Property in the Information Age, Law and Contemporary Problems, 66, 89-110.

Schrogl, K.-U., Adriaensen, M., Giannopapa, C., Hays, P. L., Robinson, J. \& Antoni, N. (eds) (2020). Handbook of Space Security. Policies, Applications and Programmes. 2 vols, 2nd edition, New York: Springer.

Scott, K. N. \& VanderZwaag, David L. (2020). Research Handbook on Polar Law. Cheltenham, UK and Northampton, MA, USA: Edward Elgar Publishing.

Shaw, M. N. (2017). International Law. 8th edn. Cambridge: Cambridge University Press.

Soares, Guido Fernando Silva (2002). Curso de Direito Internacional Público. Leiden, The Netherlands: Atlas.

Soroos, M. S. (2001). Global Environmental Policies. In Ho-Won Jeong, Global Environmental Policies: Institutions and Procedures (pp. 39-65). Cham, Switzerland: Springer.

Stahn, C. (2010). The Law and Practice of International Territorial Administration. Cambridge: Cambridge University Press.

Steer, C. (2017). Global Commons, Cosmic Commons: Implications of Military and Security Uses of Outer Space, Georgetown Journal of International Affairs, 18(1), 9-16.

Sundahl, M. J. \& Gopalakrishnan, V. (ed.) (2011). New Perspectives on Space Law. Paris: International Institute of Space Law.

Sutch, P. \& Roberts, P. (2019). Outer Space and Neo-Colonial Injustice: Distributive Justice and the Continuous Scramble for Dominium, International Journal of Social Economics, 46(11), 1291-1304. DOI: 10.1108/IJSE-03-2019-0152.

Tronchetti, Fabio (2013). Fundamentals of Space Law and Policy. Cham, Switzerland: Springer.

UNGA (1996). United Nations General Assembly Resolution (A/RES/51/123) International Cooperation in the Peaceful Uses of Outer Space.

Vogler, J. (2012). Global Commons Revisited, Global Policy, 3(1), 61-71.

Von der Dunk, F. \& F. Tronchetti (eds) (2015). Handbook of Space Law. Cheltenham, UK and Northampton, MA, USA: Edward Elgar Publishing.

Wikipedia (2015). Commercial Space Launch Competitiveness Act of 2015, at https:// en.wikipedia.org/wiki/Commercial_Space_Launch_Competitiveness_Act_of_2015.

1979 Agreement Governing the Activities of States on the Moon and Other Celestial Bodies. In force 11 July 1984.

1967 Treaty on Principles Governing the Activities of States in the Exploration and Use of Outer Space, Including the Moon and Other Celestial Bodies. In force 10 October 1967. 